\title{
高速・ニッケル/リン合金電鋳技術の開発と マイクロ研削用工具への応用*
}

\author{
仙 波 卓 弥*1, 笠 \\ 優*2

\section{Development of High-Speed $\mathrm{Ni} / \mathrm{P}$ Electroforming Technique for Fabricating Microgrinding Tool} \\ Takuya SEMBA*3 and Yutaka KASA \\ ${ }^{* 3}$ Department of Intelligent Mechanical Engineering, Fukuoka Institute of Technology, \\ 3-30-1 Wajirohigashi, Higashi-ku, Fukuoka-shi, Fukuoka, 811-0295 Japan

\begin{abstract}
An attempt to develop a high-speed electroforming technique that can produce fine nickel/ phosphorous alloy at high speed was made, in order to fabricate a microgrinding tool with superior bending strength. The amount of phosphorous acid dissolved in the plating solution was increased in order to decrease the deposited $\mathrm{Ni} / \mathrm{P}$ grain size. The amount of nickel hydroxide that is commonly used for adjusting the $\mathrm{pH}$ of the plating solution to a fixed value was used to increase the current efficiency for high-speed electroforming. In addition, citric acid was employed as a $\mathrm{pH}$ buffer agent to prevent plating burn when the amount of nickel oxide increased. The current efficiency was successfully increased from 5 to $60 \%$ by using a citric bath where the $\mathrm{pH}$ of the plating solution was increased by the addition of nickel hydroxide. In addition, it was verified through the bending test that an electroformed coating with a deposited $\mathrm{Ni} / \mathrm{P}$ grain size of $20 \AA$ pocessed the same bending strength as the cemented carbide that is commonly used for the cutting tool.
\end{abstract}

Key Words : Electroformed Tool, Microgrinding Tool, Nickel/Phosphorous Plating, High-Speed Electroforming

\section{1. 緒 論}

MEMS $や$ LIGA プロセスでは造ることが難しい微 細な三次元形状を創成する手段として, マイクロ切削 やマイクロ研削といった, マイクロ機械加工技術の開 発が行われている。なかでもマイクロ切削に関する研 究は盛んであり(1), 機械要素技術や工具技術に関する 技術開発はほぼ完成されているように判断される。

マイクロ切削と異なり, マイクロ研削はガラスやセ ラミックスなどの硬脆材料に対して微細形状を創成で きる特徴をもっている。しかし，耐欠損性に優れた極 微粒の研削工具を製造できる工具技術の開発が遅れて おり, 微小径の研削工具を回転させる方式でのマイク 口研削加工(2) はほとんど行われていない.

この極微粒の研削工具に関する耐欠損性を増すため には，砥粒を分散させた状態で固定化できる砥粒の分 散技術や, 耐欠損性に優れた工具素材を開発する必要 がある。これら新技術のうち，砥粒の分散に関しては， 砥粒表面の等電点を変えることにより砥粒の分散状態

* 原稿受付 2002 年 9 月 18 日

*1 正員, 福岡工業大学工学部 $(811-0295$ 福岡市東区和白東 3-30-1).

*2 福岡工業大学大学院工学研究科.

E-mail : senba@ fit.ac.jp
が均一な電鋳皮膜を造ることに成功している(3).

本論文ではニッケル/リン合金めつきを行い, 電析 するニッケルの結晶サイズを微細化することにより， 工具素材として使用する電鋳皮膜 ${ }^{(4)}$ の耐久損性を増 すことを試みた。 また, $\mathrm{pH}$ 緩衝剂としてクエン酸を 使用し，めっき焼けを防止することにより(5), 耐欠損 性に優れた工具素材を短時間で製造することを試み た.

\section{2. 理 論的背景}

$2 \cdot 1$ リンの誘起共析電気ニッケル/リン合金め っきでは, 式 (1)〜 (3)の反応により, 微細化剤とし て使用する垔りン酸 $\mathrm{H}_{3} \mathrm{PO}_{3}$ に含まれるリン $\mathrm{P}$ が皮膜 に取り込まれる(5).

$$
\begin{aligned}
& \mathrm{H}_{3} \mathrm{PO}_{3}+3 \mathrm{H}^{+}+3 \mathrm{e}^{-} \rightarrow \mathrm{P}_{\mathrm{ad}}+3 \mathrm{H}_{2} \mathrm{O} \\
& \mathrm{Ni}^{2+}+2 \mathrm{e}^{-} \rightarrow \mathrm{Ni}_{\mathrm{ad}} \\
& \mathrm{nNi}_{\mathrm{ad}}+\mathrm{P}_{\mathrm{ad}} \rightarrow \mathrm{NinP}
\end{aligned}
$$

式 (1)の $\mathrm{P}_{\mathrm{ad}}$ は結晶成長点に吸着し, 電析するニッケ ルの結晶成長を抑えるために結晶粒が微細化する(6). 一方, リンは電気絶縁体であるため, 式 ( 3 ) の反応が 活性化するに従って皮膜表面の電気抵抗が増加し, 電 流効率が低下する.

$2 \cdot 2$ クエン酸の効果 $\mathrm{pH}$ 緩衝性が低いめつき 


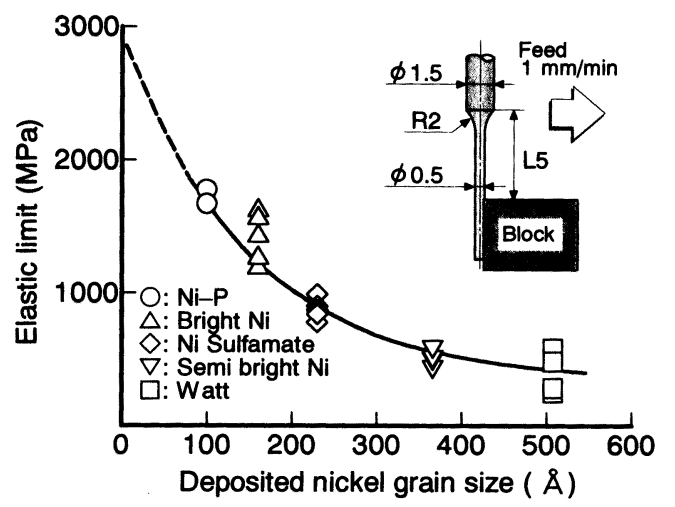

Fig. 1 Elastic limit vs deposited nickel grain size obtained by varying plating solutions

浴を用いた場合には，陰極近傍の急激な $\mathrm{pH}$ の上昇に よって式(4)のように亜リン酸ニッケル $\mathrm{NiPHO}_{3}$ が 生成され, めっき焼けが発生する。

$$
\mathrm{Ni}^{2+}+\mathrm{H}_{3} \mathrm{PO}_{3} \rightarrow \mathrm{NiPHO}_{3}+\mathrm{H}_{2}
$$

一方, クエン酸は $\mathrm{pH}$ 緩衝性が強く, 式(4)の反応を 抑制する効果がある(5). また, クエン酸濃度が増加す るとクエン酸によって錯化されるニッケルイオンが増 加し, 式( 2 )の反応が抑制される(7). その結果として, 皮膜に取り込まれるリンの含有量が増すために電析す るニッケルの結晶粒が微細化する.このように, クエ ン酸は $\mathrm{pH}$ 緩衝剤としてだけでなく, 微細化剤として も作用する。

$2 \cdot 3$ 皮膜の曲げ強さと結晶サイズ すでに開発 している高速・電鋳工具製造装置(4) を使用し，断面が $\square 2 \mathrm{~mm}$, 長さが $15 \mathrm{~mm}$ のニッケル電鋳皮膜を試作 した. ワット浴, 反光沢ニッケルめつき浴, 光沢ニッ ケルめっき浴, スルファミン酸めっき浴ならびに市販 のニッケル/リン合金めっき浴 ${ }^{(8)}$ といった 5 種類のめ つき浴を使用した。

メタルボンドホイール SD 600 Q 100 MW 6 を用い て皮膜を図 1 に併記した形状に成形した後, 動力計 (キスラ社製 9254)に設置したブロックに皮膜を押し 当てることにより，片持支持された皮膜に対する曲げ 試験を行った。式( 5 )より弾性限度 ${ }^{(9)} \sigma_{e}, \mathrm{X}$ 線回折 法(10)を用いてニッケルの結晶サイズを求めると, 弾 性限度と結晶サイズとの関係は図 1 のようにまとめら れる。

$$
\sigma_{e}=32 \cdot W_{e} \cdot l /\left(\pi \cdot d^{3}\right)
$$

ここで, $W_{e}$ は弾性限度荷重, $l$ は皮膜の長さ,ならび に $d$ は皮膜の直径である.

図 1 に示したように, 皮膜の弾性限度は電析する二
Table 1 Plating solution and conditions used for plat-

\begin{tabular}{|c|c|}
\hline Solution & $\begin{array}{l}\text { Sulfate hexahydrate } \mathrm{N}_{\mathrm{SO}} \cdot 6 \mathrm{H}_{2} \mathrm{O}: 150 \mathrm{~g} / \\
\text { Chloride hexahydrate } \mathrm{N}_{1} \mathrm{Cl}_{2} \cdot 6 \mathrm{H}_{2} \mathrm{O}: 150 \mathrm{~g} / \\
\text { Phosphorous acid } \mathrm{H}_{3} \mathrm{PO}_{3}: 0 \sim 105 \mathrm{~g} / \\
\text { Boric acid } \mathrm{H}_{3} \mathrm{BO}_{3}: 30 \mathrm{~g} / \mathrm{l} \\
\left(\mathrm{Citric} \text { acid } \mathrm{C}_{6} \mathrm{H}_{8} \mathrm{O} \cdot \mathrm{H}_{2} \mathrm{O}: 0 \sim 200 \mathrm{~g} / \mathrm{l}\right) \\
\text { Nickel hydroxide } \mathrm{Ni}(\mathrm{OH})_{2}: 0 \sim 100 \mathrm{~g} / 1\end{array}$ \\
\hline Conditions & $\begin{array}{l}\text { Cathode: Stainless steel }(25 \times 35 \times 1 \mathrm{~mm} \text { ) } \\
\text { Cathode current density: } 5 \mathrm{~A} / \mathrm{dm}^{2} \\
\text { Anode: Ni plate }(99.999 \%) \\
\text { Bath temperature: } 50^{\circ} \mathrm{C} \\
\text { Deposited film thickness: } 25 \sim 35 \mathrm{ì} \mathrm{m}\end{array}$ \\
\hline
\end{tabular}
ing test

ッケルの結晶サイズが微細化するに従って増加する性 質をもっている，ただし，市販のニッケル/リン合金 めっき浴(8)を用いた場合には結晶サイズが $100 \AA$ 以 下の皮膜を造れなかった。

\section{3. 実 験 方 法}

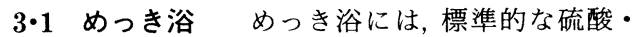
塩化ニッケル形のニッケル/リン合金めっき浴 ${ }^{(11)}$ を使 用した，表 1 にめっき浴の組成とめっき条件を示して いる. 微細化剂として亜リン酸 $\mathrm{H}_{3} \mathrm{PO}_{3}, \mathrm{pH}$ 緩衝剂と してほう酸 $\mathrm{H}_{3} \mathrm{BO}_{3}$ とクエン酸 $\mathrm{C}_{6} \mathrm{H}_{8} \mathrm{O}_{7} \cdot \mathrm{H}_{2} \mathrm{O}, \mathrm{pH}$ 調 節剤として水酸化ニッケル $\mathrm{Ni}(\mathrm{OH})_{2}$ を使用した.

$3 \cdot 2$ 電流効率 ファラデーの第 2 法則より, 電 析するニッケルの重さ $W_{N}$ は,

$$
W_{N}=I_{k} \cdot S \cdot W_{T} \cdot T \cdot \alpha
$$

と求められる(12).ここで $I_{k}$ は陰極電流密度, $S$ は陰 極の面積, $W_{T}$ はニッケルの電気化学当量, $T$ はめつ き時間，ならびに $\alpha$ は電流効率である，本論文では $\square$ $30 \times 1 \mathrm{~mm}$ のステンレス板にニッケルをめっきし，め つきの前後でステンレス板の重さを測定することによ って電流効率を測定した.

$3 \cdot 3$ ニッケルの結晶サイズ＼cjkstart電析したニッケル の結晶サイズの測定には，X 線回析法(10) を使用した。 $\mathrm{X}$ 線回析によって生じるピークの半值幅と回折角を Sherrerの式(10) に代入することにより，ニッケルの結 晶サイズを測定した。なお, 測定の分解能は $10 \AA$ で ある。

\section{4. ほう酸浴の問題点}

4 •1 結晶サイズと垔リン酸 $\mathrm{pH}$ 緩衝剤として ほう酸を使用し，ニッケル/リン合金めっきを行った. めっき浴に添加する覀リン酸濃度を $20 \sim 100 \mathrm{~g} / 1$ の範 囲で変化させた場合に得られたニッケルの結晶サイ ズ，電流効率と垔リン酸濃度との関係を図 2 に示す。 


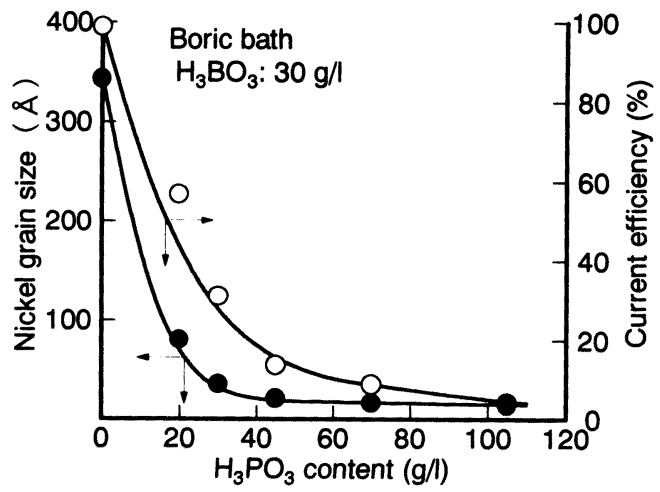

Fig. 2 Deposited nickel grain size, current efficiency vs content of phosphorous acid obtained using boric bath

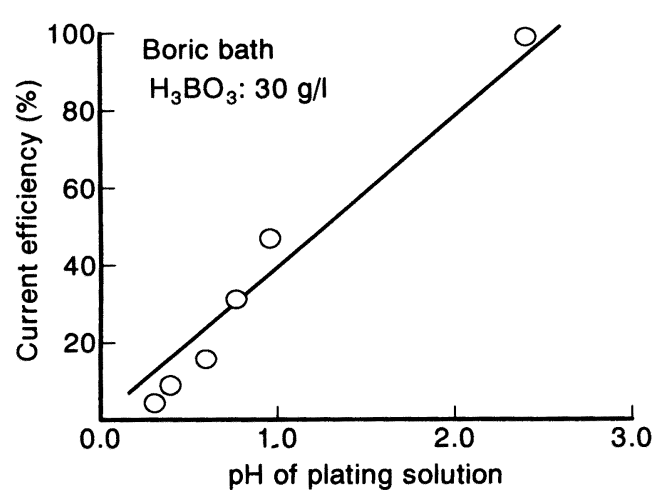

Fig. 3 Current efficiency vs $\mathrm{pH}$ of plating solution obtained using boric bath

亜リン酸を添加しない場合に $340 \AA$ 程度であった ニッケルの結晶サイズは, 亜リン酸を $45 \mathrm{~g} / 1$ 添加する と $20 \AA$ 程度に微細化した. ただし, 式( 6 )のように 表される電流効率は $100 \%$ から $20 \%$ 以下に減少した. したがって, 厚地の電鋳皮膜を短時間で造るためには, 電流効率を増す必要があると判断された。

$4 \cdot 2$ 電流効率と水酸化ニッケル 図 2 と同様, めっき浴に添加する亜リン酸濃度を $20 \sim 100 \mathrm{~g} / 1$ の範 囲で変化させた場合に得られた, めっき浴の $\mathrm{pH}$ と電 流効率との関倍を図 3 に示す. めつき浴の $\mathrm{pH}$ と電流 効率との間には正の相関があり, 電流効率を增すため にはめっき浴の $\mathrm{pH}$ を上げる必要があると考えられ た。そこで, 通常は $\mathrm{pH}$ 調節剤として使用する水酸化 ニッケルを,めっき浴の $\mathrm{pH}$ を上げる手段として使用 した.

図 4 にめっき浴の $\mathrm{pH}$ と亜りン酸濃度との関係を示 している. パラメータには水酸化ニッケルの添加量を

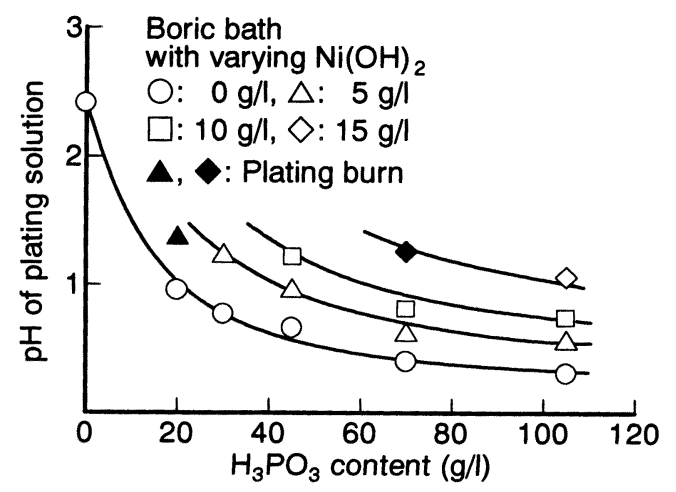

Fig. 4 pH of plating solution vs phosphorous density obtained by adding nickel hydroxide to boric bath

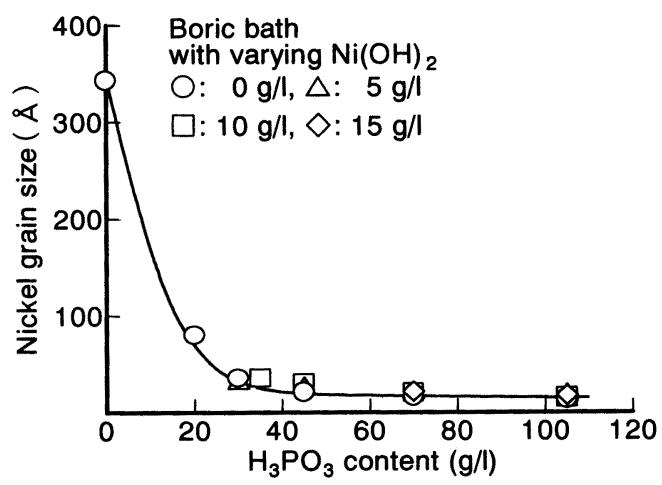

Fig. 5 Deposited nickel grain size vs phosphorous density obtained by adding nickel hydroxide to boric bath

使用した．亚リン酸濃度を変化させた各場合とも，め つき浴の $\mathrm{pH}$ が 1.3 付近で式 ( 4 ) の反応によって緑色 の亜リン酸ニッケルが陰極の表面に生成され, めっき 焼けが発生した。

図 5 に二ッケルの結晶サイズと亜リン酸濃度との関 係, 図 6 亿電流効率と覀リン酸濃度との関係を示して いる. 亜リン酸濃度が $45 \mathrm{~g} / 1$ 以下の場合には, めっき 浴の $\mathrm{pH}$ を上げることにより, 電析するニッケルの結 晶サイズはほとんど変えないで, 電流効率を最高で 60\%程度まで上げることができた。

ただし，西りン酸濃度が $70 \mathrm{~g} / 1$ 以上の場合には，め っき焼けが原因で電流効率を大幅に増加させることが できなかった。そこで, ほう酸に比べると $\mathrm{pH}$ 緩衝性 が強いクエン酸を $\mathrm{pH}$ 緩衝剤として使用し，めっき焼 けを抑えることを試みた。 


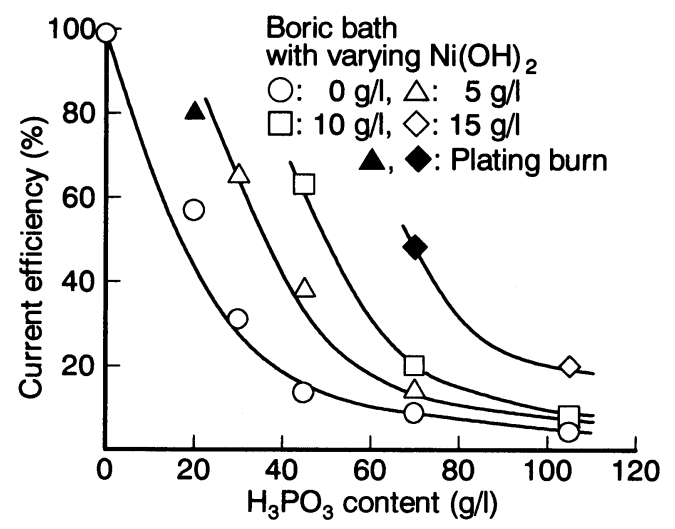

Fig. 6 Current efficiency vs phosphorous density obtained by adding nickel hydroxide to boric bath

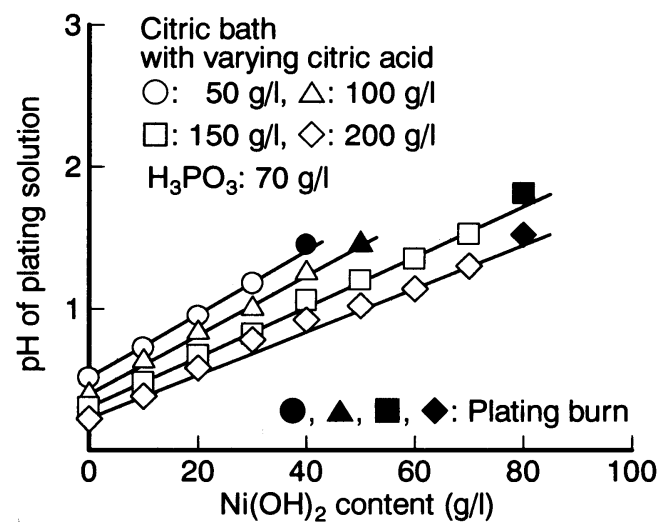

Fig. $7 \mathrm{pH}$ of plating solution vs content of nickel hydroxide obtained by varying density of citric acid in plating solution

\section{5. クェン酸の濃度}

$5 \cdot 1$ クエン酸の $\mathrm{pH}$ 緩衝性めつき浴へ添加す る垔リン酸濃度を $70 \mathrm{~g} / 1$ に固定したうえで, 水酸化二 ッケルの濃度を変化させた場合に得られた, めつき浴 の $\mathrm{pH}$ と水酸化ニッケル濃度との関係を図 7 に示す. パラメータにはクエン酸の添加量を用いている.

図 4 に示したように, 覀リン酸濃度が $70 \mathrm{~g} / 1$ のほう 酸浴を用いた場合には, 水酸化ニッケルを $10 \mathrm{~g} / 1$ 添加 すればめっき浴の $\mathrm{pH}$ を 1.0 に上げることができた. これに対して, 例えばクエン酸濃度が $200 \mathrm{~g} / 1$ の場合, めつき浴の $\mathrm{pH}$ を 1.0 に上げるためには水酸化ニッケ ルを $60 \mathrm{~g} / 1$ 添加する必要があった.このようにクエ ン酸の $\mathrm{pH}$ 緩衝性は極めて強いことが確かめられた。

$5 \cdot 2$ クエン酸の添加量 図 7 の結果と対応する,

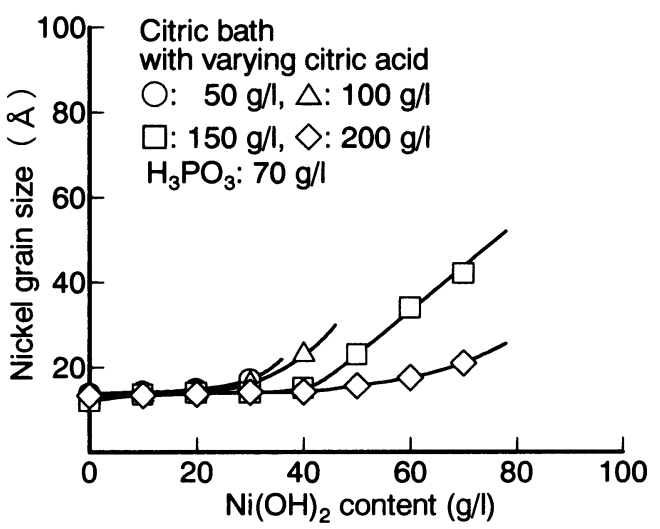

Fig. 8 Deposited nickel grain size vs nickel hydroxide density obtained by varying density of citric acid in plating solution

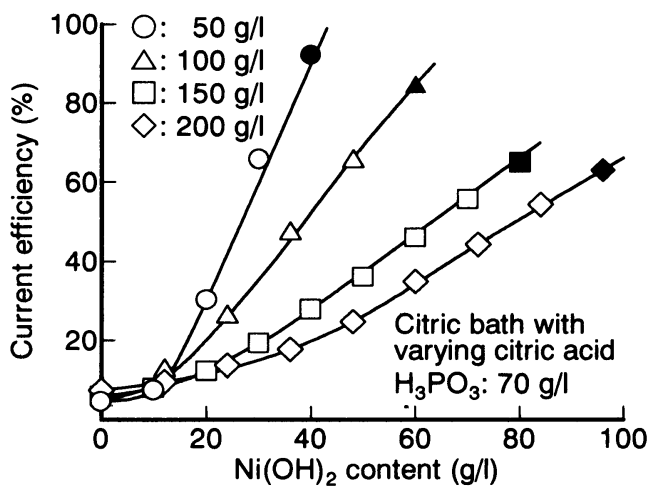

Fig. 9 Current efficiency vs nickel hydroxide density obtained by varying density of citric acid in plating solution (black symbols: plating burn)

ニッケルの結晶サイズと水酸化ニッケル濃度との関係 を図 8 , 電流効率と水酸化ニッケル濃度との関係を図 9 に示している.クエン酸濃度を増すと式 ( 2 )の反応 が抑制されるため, 結晶サイズや電流効率は減少する ことが確かめられた。

ただし, 電流効率が最も低いクエン酸濃度が $200 \mathrm{~g} /$ 1の場合でも, 電流効率を最高で $50 \%$ にげることが できた．図 6 に示したように，覀リン酸濃度が $70 \mathrm{~g} / 1$ のほう酸浴に関する電流効率が最高でも $20 \%$ あっ たことに比べると, 電流効率は 2.5 倍増加したことに なる。

図 7 の結果から,クエン酸濃度が増すに従ってめっ き浴の $\mathrm{pH}$ 緩衝性は増加するが, クエン酸濃度が 150 $\mathrm{g} / 1$ 以上の場合には $\mathrm{pH}$ 緩衝性に差はないと判断され た.また図 8 や図 9 の結果から, ニッケルの結晶サイ 


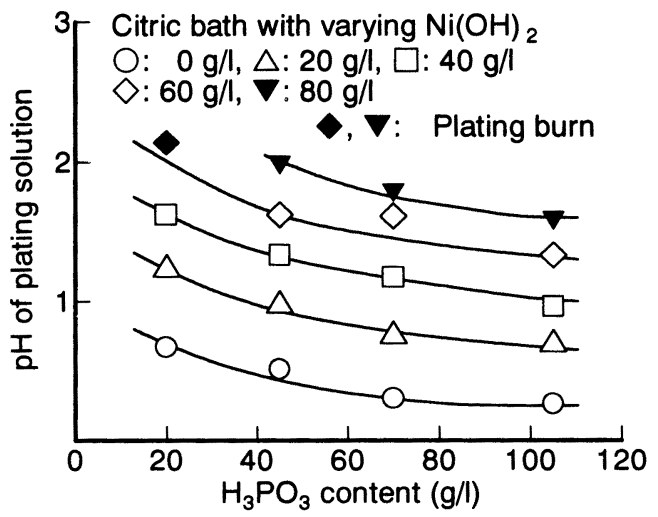

Fig. $10 \mathrm{pH}$ of plating solution vs density of phosphorous acid obtained using citric bath

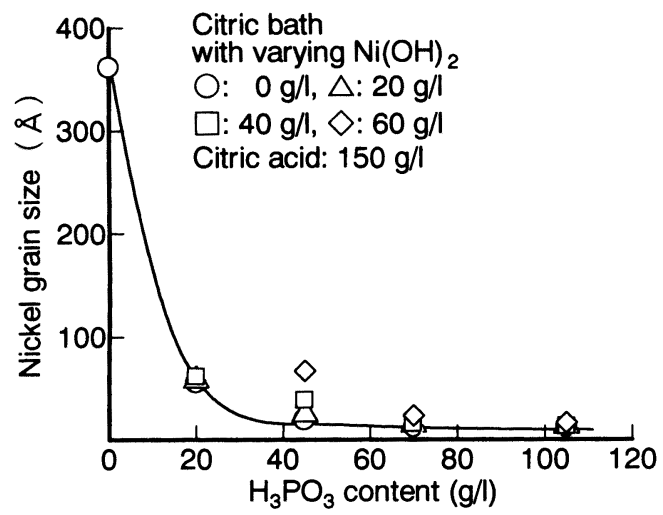

Fig. 11 Deposited nickel grain size vs density of phosphorous acid obtained using citric bath

ズが同じ場合には,クエン酸濃度が増すに従って電流 効率が減少することが確かめられた。 そこで, めっき 浴にはクエン酸を $150 \mathrm{~g} / 1$ 添加することにした.

\section{6. クエン酸浴の特性}

$6 \cdot 1$ ほう酸浴との比較 クエン酸浴を用いた場 合に得られた, めっき浴の $\mathrm{pH}$ と覀リン酸濃度との関 係を図 10 に示す。ほう酸浴を用いた場合に図 4 のよ うに得られていた実験の結果に比べ，めっき浴の $\mathrm{pH}$ を約 2 倍程度上げることができた。

図 11 にニッケルの結晶サイズと要リン酸濃度との 関係, 図 12 に電流効率と亜リン酸濃度との関係を示 している. 覀リン酸濃度が $70 \mathrm{~g} / 1$ 以上の領域では, 水 酸化ニッケルの添加量を変化させたとしても結晶サイ ズはほとんど変化していない.また，ほう酸浴に比べ ると, とくに要リン酸濃度が $70 \mathrm{~g} / 1$ 以上の領域におい て, 電流効率を増加させることができた.

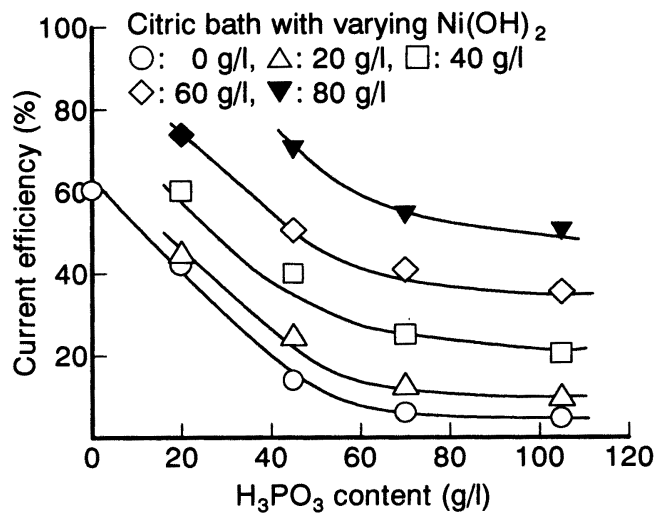

Fig. 12 Current efficiency vs density of phosphorous acid obtained using citric bath (black symbols : plating burn)

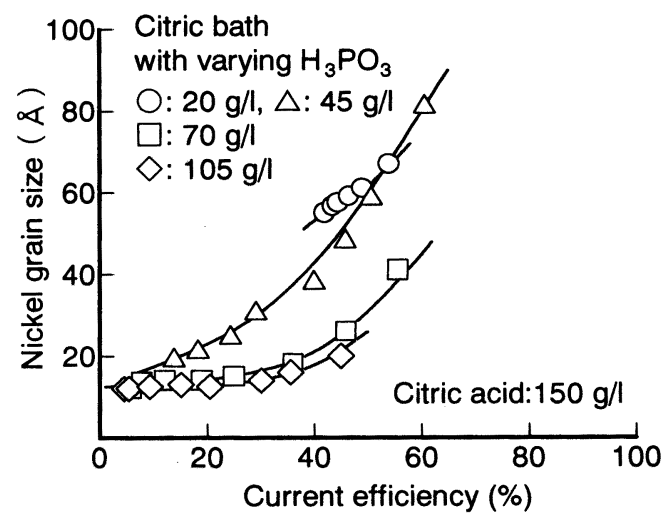

Fig. 13 Deposited nickel grain size vs current efficiency using citric bath

6・2 結果のまとめ 図 11 と図 12 の結果をもと にして, ニッケルの結晶サイズと電流効率との関係を 求めると図 13 の結果を得る。図 2 に示したように, ほう酸浴を用いた場合にも結晶サイズが $20 \AA$ 以下の 皮膜を造ることができた。ただし，この場合の電流効 率は $20 \%$ 以下に低下した。これに対してクエン酸浴 を用いた場合には，電流効率を $50 \%$ 程度にまで上げる ことができた.

\section{7. ニッケル/リン合金めっき皮膜の特性}

図 13 の結果をもとに, 電流効率が $40 \%$ になるよう にめっき浴の $\mathrm{pH}$ を調節し，覀リン酸濃度を 20 ～105 $\mathrm{g} / 1$ の範囲で変化させた 4 種類の電鋳皮膜を試作し た.また，試作した皮膜に対する曲げ試験を行った。 比較のため, P 20 種の超微粒子超硬合金を同じ形状に 成形した試験片についても同様の曲げ試験を行った。 式(1)のように求められる弾性限度と結晶サイズと 


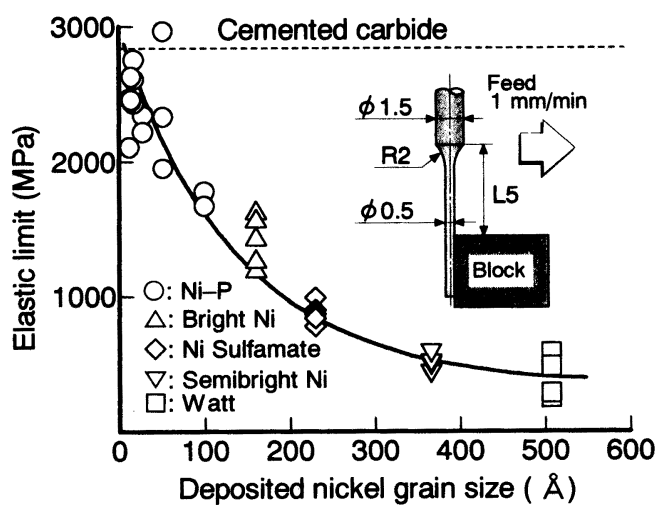

Fig. 14 Elastic limit vs deposited nickel grain size obtained by varying plaring solutions

の関係を図 14 に示している.図 14 に併記した破線 は, P 20 種の超微粒子超硬合金に関する欠損応力を示 している．結晶サイズが $20 \AA$ 以下のニッケル/リン 合金皮膜に関する弾性限度は約 $2800 \mathrm{MPa}$ であり，超 微粒子超硬合金とほほ同じ曲げ強さをもつことが確か められた。

\section{8. 結 論}

ニッケル/リン合金めっきを行い, 電析するニッケ ルの結晶サイズを微細化することにより工具素材とし て使用する電鋳皮膜の耐欠損性を増すことを試みた. 本論文で得られた研究の成果は，以下のようにまとめ られる。

（1）クエン酸浴を使用し電析するニッケルの結晶 サイズが $20 \AA$ 以下になるようにめっき浴の $\mathrm{pH}$ を調 節した場合には, P 20 種の超微粒子超硬合金とほほ同 じ耐欠損性をもつ電鋳皮膜を造ることができた。
（2）ほう酸浴に比べ $\mathrm{pH}$ 緩衝性が強いクエン酸浴 を用いた場合には，めっき浴の $\mathrm{pH}$ を 2.0 付近まで上 げることができた。その結果, 結晶サイズが $20 \AA$ 以 下の電鋳皮膜を最高で $50 \%$ 程度の電流効率で造るこ とができた。

（3）通常のほう酸浴を用いたとしても，めっき浴 の $\mathrm{pH}$ を上げることにより電流効率を上げることがで きる、ただし，亜りン酸濃度が $70 \mathrm{~g} / 1$ 以上の場合に は, めっき焼けが原因で電流効率を $20 \%$ 以上に上げる ことができなかった。

\section{文献}

（1）竹内芳美, マイクロ切削加工, 精密工学会誌, 68-2 (2002), 167-170.

(2) Gäbler, J., Schäfer, L., Wenda, A. and Hoffmeister, H. W., Development and Application of CVD Diamond Micro Tools for Milling and Grinding, Proc. 1st EUSPEN Conf. Bremen, 1 (1999), 434-437.

（3）仙波卓弥・田中秀司・竹内恵三，極微粒ダイヤモンド研 粒を用いた多層電着工具の開発，機論，66-643, C (2000), 361-367.

（4）仙波卓弥・冨田直樹 - 藤井晋一, 高速・電鋳工具製造技 術の開発, 機論, 69-679, C (2003), 217-223

（5）森河努，非金属誘起共析型合金めっきに関する研究 (1995), http://www.tri.pref.osaka.jp/group/surface/ Morikawa/Doc/main.html

（6）増本健・渡辺徹, アモルファスメッキ法とその応用, (1990)，3，日刊工業.

（7）石川正巳・榎本英彦, ニッケルークエン酸めっき浴におけ るニッケルークエンの錯平衡, 表面技術, 40-11（1989）, 116-121.

（8）キザイ(株),ナイホロイプロセス（新しい硬質ニッケルめ つき法)，技術資料，(1971）。

（9）清水篤榣, 改訂材料力学, (1963), 83, 共立出版.

(10) 理学電機(株) 分析セン夕、X 線回折の手引き（改訂第 4 版), (1992), 75 .

（11）伊勢秀夫, 電鋳技術と応用, (1996)，138, 㮁書店.

（12）川崎元雄・榎本英彦，めっき教本，(1997)，609，日刊工業。 